http://kitaibelia.unideb.hu/

ISSN 2064-4507 (Online) • ISSN 1219-9672 (Print)

(C) 2015, Department of Botany, University of Debrecen, Hungary

20 (2): 268-285; 2015

DOI: $10.17542 /$ kit.20.268

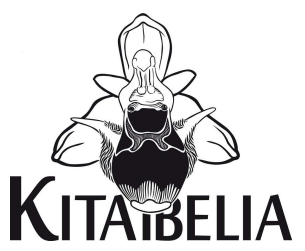

\title{
Az év vadvirága 2014-ben: a szibériai nőszirom (Iris sibirica L.)
}

TAKÁCs Attila1*, NAgY Timea ${ }^{2}$, SAlamon-Albert Éva ${ }^{3}$ \& Molnár V. Attila ${ }^{1}$

(1) Debreceni Egyetem TTK Növénytani Tanszék, H-4010, Debrecen, Pf. 14.; *limodorum.abortivum@gmail.com (2) Pannon Egyetem GK Növénytudományi és Biotechnológiai Tanszék, H-8360 Keszthely, Festetics u. 7.

(3) Pécsi Tudományegyetem TTK Növénybiológiai Tanszék, H-7624 Pécs, Ifjúság útja 6.

\section{The Wildflower of the Year 2014 in Hungary: Siberian flag (Iris sibirica L.)}

Abstract - In this paper a review of the nomenclature, etymology, taxonomy, morphology, histology, life cycle, phenology, reproduction, habitat preference, biotic interactions, biologically active compounds, micropropagation, application possibilities and conservation status of Siberian flag (Iris sibirica L.) can be found. Leaf traits, phenological data, seed-set, thousand-seed weight, germination, growth rate and soil characteristic data are published based on original observations:

- Leaf area is between 25,3 and 52,9 $\mathrm{cm}^{2}$, its dry mass is 232 and $272 \mathrm{mg} / \mathrm{g}$, specific leaf area is 14,5 and $15,0 \mathrm{~m}^{2} / \mathrm{kg}$; based on measurement of 5-5 leaves of $I$. sibirica, collected from Tapolca and Létavértes (Hungary) in May of 2014.

- Based on herbarium dataset, blooming of I. sibirica begins at the end of April and lasts to early-July, contrary to the literature data (May-June).

- Capsules contain (0-)58-76(-121) fertile seeds. $(20-) 60-80(-90) \%$ of ovules develops to (seemingly) viable seeds, meanwhile the other ovules remain as aborted ones or develop to infertile seeds (probably because of absence of resources); based on fruits collected from Regéc (Hungary) in 2014 and 2015.

- Thousand-seed weight of I. sibirica is 8,8298-11,2914 g (based on 3×100-100 seeds collected from Regéc and Tapolca in 2014 and 2015), which is lower value than the literature data.

- In our germination test (50-50 seeds sowed to wet soil, after different treatments) $14 \%$ of scarified seeds, $6 \%$ of scalded seeds, $4-4 \%$ of imbibed and control seeds, $0-0 \%$ of cooled and refrigerated seeds are germinated. Scarified seeds germinated in the 8-26th days, imbibed seeds $15-19^{\text {th }}$ days, control seeds $16-20^{\text {th }}$ days, scalded seeds $20-23^{\text {th }}$ days after sowing. It seems that scarification stimulates, meanwhile temperature-treatments inhibit the germination. Until 18 weeks the seedlings grow to $30 \mathrm{~cm}$ (in mean) and develop 5-7 leaves (in mean). After the $14^{\text {th }}$ week, the first and littlemost lateral leaves are necrosed.

- Analyses of soil samples collected from 17 locations of I. sibirica in Hungary, suggest that the species prefers highly acidic to slightly alcalic, lime-free to highly calcareous soils with generally high amount of humus and clay, different amount of phosphorus, potassium and nitrogen and low concentration of salt.

Keywords: endangered species, flora of Hungary, Iridaceae, protected species

Összefoglalás - Jelen közlemény áttekintést nyújt a szibériai nőszirom (Iris sibirica L.) nevezéktanáról, rendszertanáról, alak- és szövettanáról, életciklusáról, fenológiájáról, szaporodásbiológiájáról, élőhelyválasztásáról, biotikus interakcióiról, hatóanyagairól, mikroszaporításáról, felhasználási lehetőségeiről és veszélyeztetettségéről. Saját megfigyelések és mérési eredmények alapján közlünk adatokat a növény levéltulajdonságairól, fenológiájáról, magképzési sikeréről, ezermagtömegéről, csirázási és növekedési erélyéről valamint termőhelyeinek talajadottságairól.

Kulcsszavak: Iridaceae, Magyarország flórája, védett fajok, veszélyeztetett fajok 


\section{Bevezetés}

Az év vadvirága mozgalom keretében évről-évre megválasztott, fokozott figyelemmel kitüntetett növényfajokról rendre ismeretterjesztő közlemények sokasága jelenik meg (vö. FARKAS \& MOLNÁR V. 2014). A Kitaibelia hasábjain 2014-ben indult sorozat célja, hogy ugyanezekről a növényekről tudományos igényű áttekintések („kismonográfiák”) is napvilágot lássanak. Jelen közleményben, e sorozat második részében, kísérletet teszünk minden, a szibériai nőszirommal (Iris sibirica L.) kapcsolatos érdemi információ összegzésére a hozzáférhető hazai és nemzetközi szakirodalom, herbáriumi anyag valamint saját vizsgálataink alapján. Közleményünk alapvetően szemle (review) jellegű, vagyis legnagyobbrészt szakirodalmi áttekintésen alapul. A saját eredmények bemutatásának célja az adatközlés, a vizsgált növény ismeretéhez való hozzájárulás, így ezek értékelésére csak a szükséges mértékben kerítünk sort.

\section{Anyag és módszer}

A levéltulajdonságok meghatározása 2014 májusában két lelőhelyről (Tapolca és Létavértes) gyüjtött 5-5 darab átlagos méretű levél felületének valamint nedves és száraz tömegének mérésén alapszik. A termések méreteit és azok magszámait egy regéci állományban 2014ben és 2015-ben gyűjtött 16 és 33 ép termésen vizsgáltuk. Az említett regéci és tapolcai állományokból gyűjtött életképesnek tűnő magok ezermagtömegét háromszor 100-100 mag mérése alapján adjuk meg. A pre- és posztzigotikusan abortált magkezdemények és az érett magok megkülönböztetésére találtunk irodalmi utalásokat (például SzőLLősI et al. 2011), tényleges megkülönböztetésük azonban tapasztalati úton történt. A 2014-ben Regécről gyưjtött érett magok bevonásával csíráztatási, majd növekedési ütem vizsgálatot indítottunk. 50-50 magot különböző kezeléseknek vetettünk alá. Ezek a következők voltak: 1) áztatás (24 órán át, szobahőmérsékleten), 2) hűtés (24 órán át, $4{ }^{\circ} \mathrm{C}$-on), 3) fagyasztás (24 órán át, -20 ${ }^{\circ} \mathrm{C}$-on, vízben), 4) forrázás (100 ${ }^{\circ} \mathrm{C}$-os vízzel, lehűlésig), 5) szkarifikálás (szikével ejtett három karcolás a mag mindkét oldalán), 6) kontroll. A kezelt illetve a kontroll magokat vízzel átitatott talajra vetettük, majd a szubsztrát folyamatos nedvesen tartásával mesterséges megvilágítás mellett (napi 14 óra, 60 W Neodynium Daylight napfényizzóval) csíráztattuk. Feljegyeztük a magok csírázási dátumát, majd 18 héten keresztül figyelemmel kísértük a csíranövények növekedési erélyét (levelek hosszúságának és számának változását). A 20. hétig hetente, ezt követően havonta egy alkalommal mértük a leghosszabb levél hosszát és feljegyeztük a levelek számát.

A fenológiai és elterjedési adatokat a BP, BPU, DE és EGR herbáriumokból gyűjtöttünk, összesen 135, Magyarország területén gyüjtött példány feldolgozásával. A 17 hazai lelőhelyen gyökérmélységből gyűjtött talajmintákat a Debreceni Egyetem Agrártudományi Központ Karcagi Kutatóintézet és a Minerág Kft. (Szekszárd) akkreditált laboratóriumai vizsgálták.

\section{Nevezéktan, etimológia}

Tudományos neve: Iris sibirica L. 1753 Species Plantarum 1: 39.

$\mathrm{Az}$ ógörög eredetű Iris szó jelentése szivárvány, amely növényünk esetében a nemzetségbe sorolt fajok virágainak rendkívül változatos színére utal. Carolus Clusius Iris angustifolia media névvel illette az 1500-as években (STEBBINGS 1997), de ma érvényes nevét LiNNAEUS (1753: 39.) alkotta meg; élőhelyeként Ausztria, Svájc és Szibéria rétjeit jelölte meg, utóbbi területről nevezte el a fajt. Nevét (a subgenus Limniris genus rangra emelésével) többek között Limnirion sibiricum (L.) Opiz és Limniris sibirica (L.) Fuss-ként is 
újrakombinálták, ma azonban általánosan elfogadott a faj Iris nemzetségen belül való tárgyalása.

Európai nyelvekben neve jellemzően a latin név tükörfordítása, így angolul Siberian flag, németül Sibirische Schwertlilie, franciául L'iris de Sibérie, olaszul giaggiolo siberiano, szlovákul és csehül kosatec sibiřský, lengyelül kosaciec syberyjski, szerbül Сибирски Ирис (Sibirski Iris), horvátul és szlovénül sibirska perunika, oroszul úpuc сиби́рский (íris sibírskiy), ukránul пі́вники сибі́рські (pívnyky sybírski), románul stânjenelul siberian néven ismeretes. Nőszirom szavunkat DIósZEGI \& FAZEKAS (1807) alkották meg a sziromszerúen kiszélesedő bibekaréjok alapján (MolNÁR V. 2007), de a köznyelvben sokáig liliom néven ismerték az Iriseket (RAPAICS 1932).

\section{Rendszertan, kariológia}

Az északi mérsékelt övben elterjedt, 300 körüli fajt számláló Iris az Iridaceae család legnagyobb nemzetsége, melynek felosztása illetve határainak megvonása számos vitás kérdést vet fel (LAWRENCE 1953, TAYLOR 1976, RODIONENKO 1987). A nemzetséget hagyományosan hat alnemzetségre osztják a szerzők. Ebben a rendszerben az I. sibirica-t a szakálltalan nőszirmok (subgenus Limniris) közé sorolták, ám az alnemzetség kloroplasztisz markerek alapján parafiletikusnak bizonyult (WILSON 2004, 2009). Az viszont kétségtelennek tűnik, hogy legközelebbi rokonai a hazánkban gyakori I. pseudacorus L. mellett az ázsiai I. laevigata Fisch., az észak-amerikai I. virginica L. és a mindkét kontinensen honos I. setosa Pall. ex Link (WILSON l. c.).

A Szlovénia, Horvátország és Bosznia területéről ismert, száraz termőhelyeken előforduló, a törzsalaknál minden részében kisebb I. sibirica L. subsp. erirrhiza (Pospichal) Wraber taxonómiai rangja vitatott, valószínűleg csak ökotípus (Cigić et al. 2006).

A faj kromoszómaszáma $2 \mathrm{n}=28$ (1. táblázat), amelyet több szerző is megerősített (például MuRin 1976, WeTSCHNIG 1988, MALAKHOVA \& MARKOVA 1994).

1. táblázat. Az I. sibirica és rokonai kromoszómaszám-adatai (GoLDBLATT \& JoHNSON 1979-2015 alapján). Table 1. Chromosome number data of I. sibirica and some related taxa (based on GoLDBLATT \& JoHNSON 1979-2015).

\begin{tabular}{lc}
\hline \multicolumn{1}{c}{ Faj / Species } & Kromoszómaszám (2n) / Chromosome number (2n) \\
\hline I. laevigata & $28,32,34$ \\
I. pseudacorus & $24,32,34$ \\
I. setosa & 36,38 \\
I. sibirica & 28 \\
I. virginica & n.d. \\
\hline
\end{tabular}

\section{Morfológia}

Az Iris sibirica alaktani jellemzését BeRnátsky (1911), Tutin (1980), SPOREK \& RoMBEL-BRYZeK (2005), KostraKIEWICZ (2008), GonTova \& ZATYLNiKova (2013) és saját megfigyelések alapján állítottuk össze:

Vaskos, hengeres, a talajban horizontálisan növekvő gyöktörzsei rövid internódiumokkal körülbelül $1 \mathrm{~cm}$ vastagságúak, hegyesszögben elágazók. A gyöktörzsek alsó oldalán erednek a gyökerek, míg a föld feletti hajtások csúcsi helyzetben fejlődnek. A rizómák sürü elágazásaival polikormonokat alkotó geofiton növény. Egy polikormon (1-)10-170(-200) virágzó hajtást hozhat. Levelei úgynevezett lovagló levelek, vagyis élükkel a szár felé fordulnak, amelyet alsó részük csatornája körülölel (a külső levelek csatornája a belső levelek külső élére „ül” rá). A levelek izolaterálisak, azaz színük és fonákuk lényegében nem különbözik. A tőlevelek egyenesek, hosszan párhuzamos élűek, alig láthatóan erezettek, 
vékony kutikula réteggel fedettek, hosszúságuk 25-60(-120) cm, szélességük 4-10 mm lehet, a szár feléig-háromnegyedéig érnek. A levéltulajdonságokat (felület, szárazanyag tartalom, fajlagos levélfelület) a 2. táblázat foglalja össze. A szár 2-3 lomblevelet visel, valamint a virágzat oldalágainak tövében $2-5 \mathrm{~cm}$ hosszúságú barnásan hártyás, szárölelő fellevelek fejlődnek. A hengeres szár vékony, átmérője 2-6 mm, magassága 25-130 cm, csak a virágzatban oldalágas. Főként szárazabb években előfordulnak „I. graminea-szerü” törpe hajtásai (DÉNES et al. 2008; Molnár V. et al. 2014. 05. 15. [DE-Soo-37926 kódú példány a Debreceni Egyetem Herbáriumában]). A szár ürege a keresztmetszet csaknem felét kitölti.

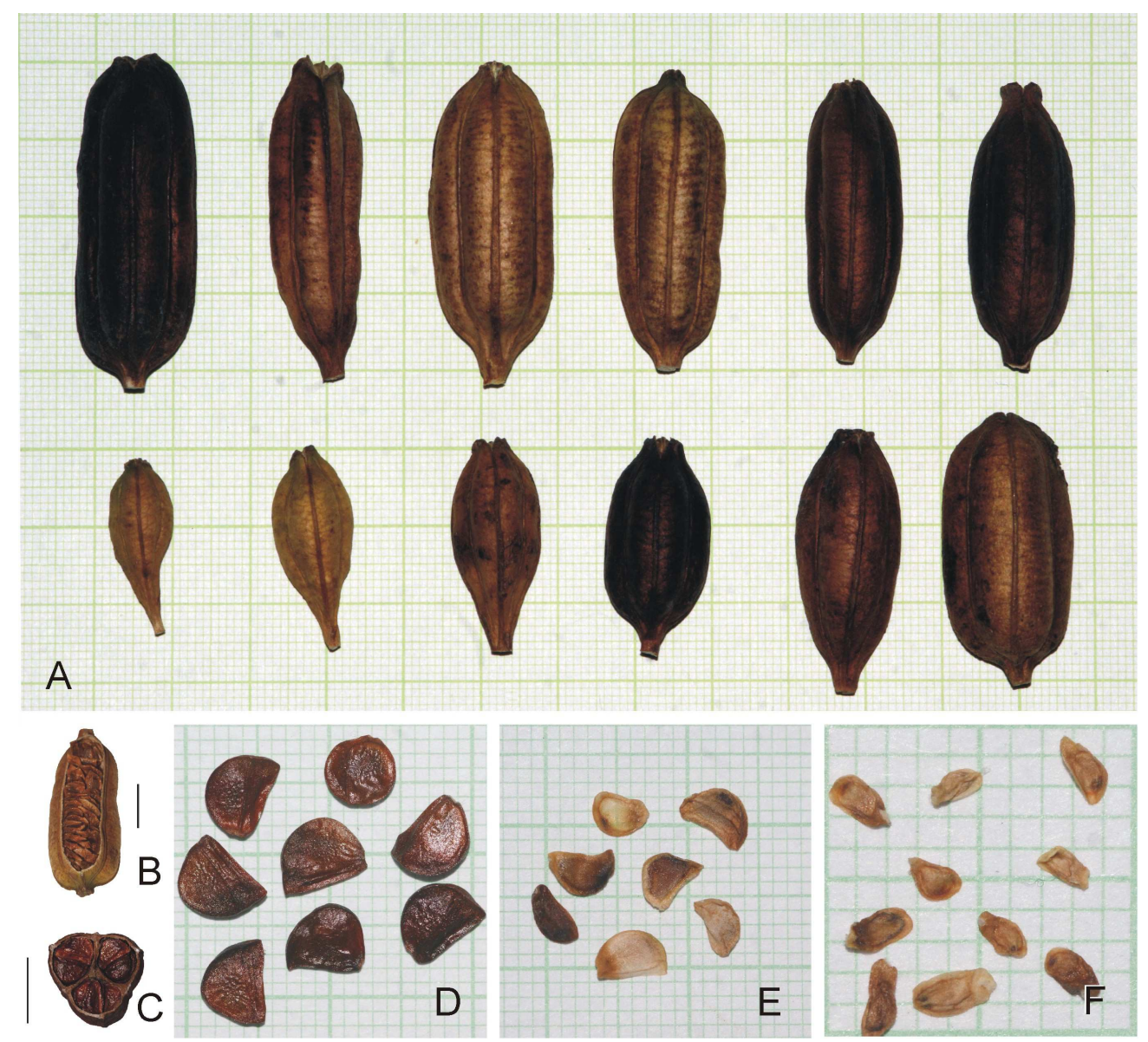

1. ábra. Az I. sibirica (A) különböző alakú és méretű termései; $(B+C)$ magjainak elhelyezkedése a termésben (méretvonal: $10 \mathrm{~mm}$ ); (D) csíraképes magjai; (E) léha magjai és (F) abortált magkezdeményei (eredeti).

Fig. 1. (A) Capsules with different size and shape; $(B+C)$ seeds in the capsule (scale bar: $10 \mathrm{~mm}$ ); (D) germinable seeds; (E) infertile seeds and (F) aborted ovules of I. sibirica (original).

Egy hajtás 1-5(-7) virágot fejleszt. A virágtakaró két körbe rendeződik: három nagyobb méretű külső lepelcimpa lefelé, három belső pedig felfelé irányul. Előbbiek fehér alapon kék vagy lilás erezetűek, alapi részükön sárgás futtatásúak, utóbbiak egyszínű kékek vagy lilásak, ritkán az egész virág fehér. A külső lepelcimpákra fekszenek a sziromszerû, széles bibekaréjok, amelyek a porzókat is takarják. A bibekaréj alsó felén, annak felső harmadában 
található a bibe háromszög alakú aktív felülete. (A virág szerkezetének ismertetését lásd a Fenológia és megporzás című fejezetben.)

A virágok legyező virágzatot (rhipidium) alkotnak, amely az egyes bog egy variációja: a virágzati tengely egy csúcsvirágban végződik, a virágzatban a következő virág kocsánya az előző virág alatt ered s áltengelyt létrehozva túlnövi azt. Az áltengelyből újabb virágkocsány ered és így tovább. A kocsányok egymással egy síkba esnek, fölfelé egyre rövidülnek. A virágzatok 1-3 szintűek lehetnek.

A magház alsó állású, a toktermés háromrekeszű, kissé szögletes (1. ábra C). A termés 1020 mm széles, 20-40 mm hosszú, változatos alakú (1. ábra A).

2. táblázat. Az I. sibirica levél tulajdonságai (eredeti adatok).

Table 2. Leaf traits of I. sibirica (original data).

\begin{tabular}{lcccccc}
\hline & \multicolumn{2}{c}{$\begin{array}{c}\text { Levélfelület / } \\
\text { Leaf area }\left(\mathbf{c m}^{2}\right)\end{array}$} & \multicolumn{2}{c}{$\begin{array}{c}\text { Szárazanyag-tartalom / } \\
\text { Dry mass }(\mathbf{m g} / \mathbf{g})\end{array}$} & \multicolumn{2}{c}{$\begin{array}{c}\text { Fajlagos levélfelület / } \\
\text { Specific leaf area (m² } \mathbf{k g})\end{array}$} \\
& Tapolca & Létavértes & Tapolca & Létavértes & Tapolca & Létavértes \\
\hline $\begin{array}{l}\text { Átlag } \pm \text { szórás } \\
\text { / Mean } \pm \text { SD }\end{array}$ & $25,3 \pm 6,1$ & $52,9 \pm 21,8$ & $232 \pm 28$ & $272 \pm 46$ & $14,6 \pm 1,6$ & $15,0 \pm 3,8$ \\
Min - max & $17,3-31,9$ & $37,2-89,9$ & $195-269$ & $228-332$ & $12,9-17,1$ & $10,9-20,7$ \\
\hline
\end{tabular}

\section{Szövettan}

A szár és a levél szövettani jellemzését PAPP (1903) és GonTova \& ZATYLNIKOVA (2013) alapján, a mag szövettani felépítését NAGY (1927) tanulmánya alapján állítottuk össze:

A szárat borító egyrétegû́ epidermisz alatt klorenchima, az alatt vékony szklerenchima található, amely elhatárolja a kortextől a központi hengert. A szklerenchima és a központi üreg között nagyméretű sejtekből felépülő bélparenchima helyezkedik el, amelybe szórtan, koncentrikus és kollaterális zárt edénynyalábok ágyazódnak, a szklerenchima gyürü közelében sürübben. A kollaterális szállítónyalábokban a faelemek félhold vagy V-alakban csoportosulnak a háncselemek mellé.

A leveleket borító megnyúlt, kissé megvastagodott falú sejtekből felépülő epidermisz helyenként papillás felszínű. A bőrszöveti sejtek a levélhüvelyen 2-3-szor hosszabbak, mint a lemezen. Sztómái tetracitikusak (a zárósejteket két poláris és két laterális melléksejt határolja). Az epidermisz alatt vékonyfalú sejtekből felépülő homogén mezofillum található, ebben rafid vagy sztiloid kristályok illetve ritkábban idioblasztok is előfordulnak. Utóbbiak flobafén típusú vegyületeket raktároznak (RODIONENKO 1987). A klorenchima sejtek az epidermisz közelében szorosabban állnak.

A levelek edénynyalábjai keresztmetszetben megnyúltak. A floém keskeny keresztmetszetű háncsparenchima elemekből és rostacsövekből épül fel. Ezt kívülről szklerenchima határolja, belülről széles lumenű xilém elemek (faparenchima, tracheák, tracheidák) kötegével szomszédos. A szilárdító szövet sejtjeinek falai aránylag vékonyak, a parenchima sejtekénél csak kissé vastagabbak. A háncs- és faszövet között kisebb átmérőjú üreg húzódik.

PAPP (1903) hangsúlyozza az I. sibirica xeromorf jellegeit: a levelek viaszosságát és a mechanikai szövet fejlettségét. Előbbit a párologtatási optimum megteremtésével magyarázza, utóbbi a hosszú, vékony levelek tartását biztosítja.

A magok felszínén a kutikulás, epidermisz sejtjei megnyúltak, hosszmetszetben téglalap alakúak, külső és belső tangenciális faluk egyenletesen, radiális faluk gödörkésen vastagodott. A köldök körüli sejtek vastagabb falúak, mint a mag felületének többi részén. Az érett mag epidermisz sejtjei üresek. A szövetben kevés sztóma van. Alatta a parenchima réteg a mag alapján és csúcsi részén a legvastagabb; benne elszórtan cseranyag tartalmú sejtek helyezkednek el. A parenchimába ágyazódó edénynyalábot megnyúlt, vastag falú, 
fásodott sejtek alkotják. A parenchima alatt az embriót palástszerűen öleli körül egy olajtartó réteg, amely az I. sibirica esetében 3-5 sejtsor vastagságú.

\section{Életciklus}

KostRAKIEWICZ (2007) szerint az Iris sibirica életciklusában hat stádium különíthető el: 1) Csíranövényei már a nyár vagy az ősz folyamán megjelennek. Ezek az első szezonban csupán néhány apró levelet fejlesztenek. 2) A második évben, azaz a juvenilis stádiumban a vegetatív szervek gyarapodása a jellemző. 3) A harmadik évben a levélrozetták száma általában már meghaladja a tízet, $\mathrm{s}$ a vegetatív szervek intenzív gyarapodása mellett 1-2 virágzó hajtás is megjelenik; ez a korai generatív stádium. 4) A negyediktől a hetedik évig tartó generatív szakaszban a legjelentősebb a növény ivaros szaporodása, míg 5) a nyolcadiktól a tizedik évig tartó elöregedő stádiumban az idősebb rizómák pusztulása jellemző: a polikormon közepéről eltűnnek a hajtások s a sarjtelep gyűrű alakban növekszik tovább. 6) A tizedik évtől a fragmentálódás szakaszába lép a növény, amikor az idősebb rizómák további pusztulása révén a sarjtelep egymástól elkülönülő rametekre tagolódik szét. DÉNES et al. (2008) a fentiekkel lényegében megegyező stádiumokat ismertek fel.

\section{Fenológia és megporzás}

Virágzása JÁvoRKA (1925), SIMON (2002) és KIRÁLY (2009) szerint május-június folyamán zajlik, míg SzőLLőSI et al. (2011) szerint virágainak nyílása melegebb években már április végén elkezdődhet. Ez utóbbit támasztják alá a hazai herbáriumokban (BP, BPU, DE, EGR) gyűjtött fenológiai adatok is (2. ábra). Ártéri populációinak virágzási idejét az árvizek befolyásolhatják (Barina Z. ex litt.). Nyárvégi-őszi másodvirágzása (például Kevey B. 1980.10.08. [BP-0494075 kódú példány a Magyar Természettudományi Múzeum CarpatoPannonicum gyűjteményében]) ritkaságnak számít. Egy-egy virága körülbelül 32 órán át nyílik (ODINTSOVA \& SKRIPETS 2014).

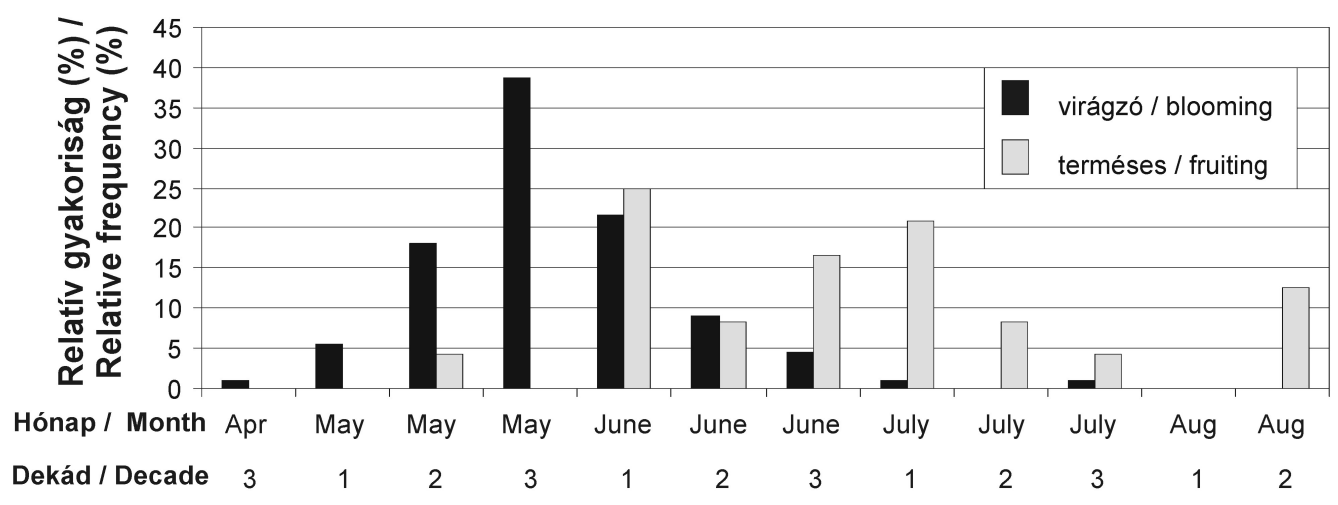

2. ábra. Az I. sibirica virágzó ( $\mathrm{n}=111)$ és terméses ( $\mathrm{n}=24)$ állapotban gyűjtött hazai herbáriumi példányainak relatív gyakorisága dekádonként (eredeti).

Fig. 2. Relative frequency of Hungarian herbarium specimens of I. sibirica collected in blooming and fruiting stage pro decades ( $\mathrm{n}=111$ and 24 , respectively) (original).

SzőLLősI et al. (2011) megfigyelései szerint a körülbelül három hétig tartó virágzás három szakaszra osztható a példányonként egy időben nyíló virágok száma alapján: az első szakaszban polikormononként 1-5, a „csúcsidőszakban” 6-10, az utolsó szakaszban 1-2 
virág nyílik naponta. Az adott év csapadék- és hőmérséklet viszonyaitól nagymértékben függ a virágzó hajtások száma, a virágok száma és a virágzat szintjeinek száma (DÉNES et al. 2008, SzŐLLốsI et al. 2011).

Az I. sibirica virágait hártyásszárnyúak (háziméh [Apis mellifera], földi poszméh [Bombus terrestris], kék fadongó [Xylocopa violacea], darazsak, fekete hangya (Lasius niger) és bogarak (szalagos maróka [Variimorda villosa], kerti cserebogár [Phyllopertha horticola], pézsmacincér [Aromia moschata]) látogatják (SzőLlősI et al. 2011, ODINTSOVA \& SKRIPETS 2014). Egy külső és két belső lepel, a sziromszerű bibekaréj és egy porzó alkot egy zigomorf megporzási egységet (meranthia, 3. ábra) (GoLDBLATT et al. 1998), amely múködésében igen hasonló a zigomorf virágokéhoz (például Lamiaceae, Orchidaceae stb.), de fontos különbség, hogy az Iris-ek esetében három zigomorf egység épít fel egy virágot. A nőszirmok külső leplei a rovar leszállóhelyéül szolgálnak, amelyek erezete vizuális ingerként vezeti a rovart a lepel tövében elhelyezkedő nektáriumokhoz. A rovar előbb a bibe aktív felületéhez ér, majd az alatta elhelyezkedő porzóhoz. A bibe aktív felszíne és a portokok térben, müködésük pedig időben elkülönül egymástól (előbb a portokok nyílnak fel, a bibe felülete ehhez képest későn válik aktívvá), kiküszöbölve ezzel az önmegporzás lehetőségét (GoLDBLATT et al. 1998). ODINTSOVA \& SKRIPETS (2014) szerint a rovarok egy virágon belül csak egy meranthiát látogatnak meg. Azonos egyed másik virágából származó pollen megtermékenyítheti az egyed más virágait (geitonogámia), saját pollenjétől azonban nem képes megtermékenyülni; a virág ön-inkompatibilis vagy ön-meddő ('self-incompatible') (GoLDBLATT et al. 1998).

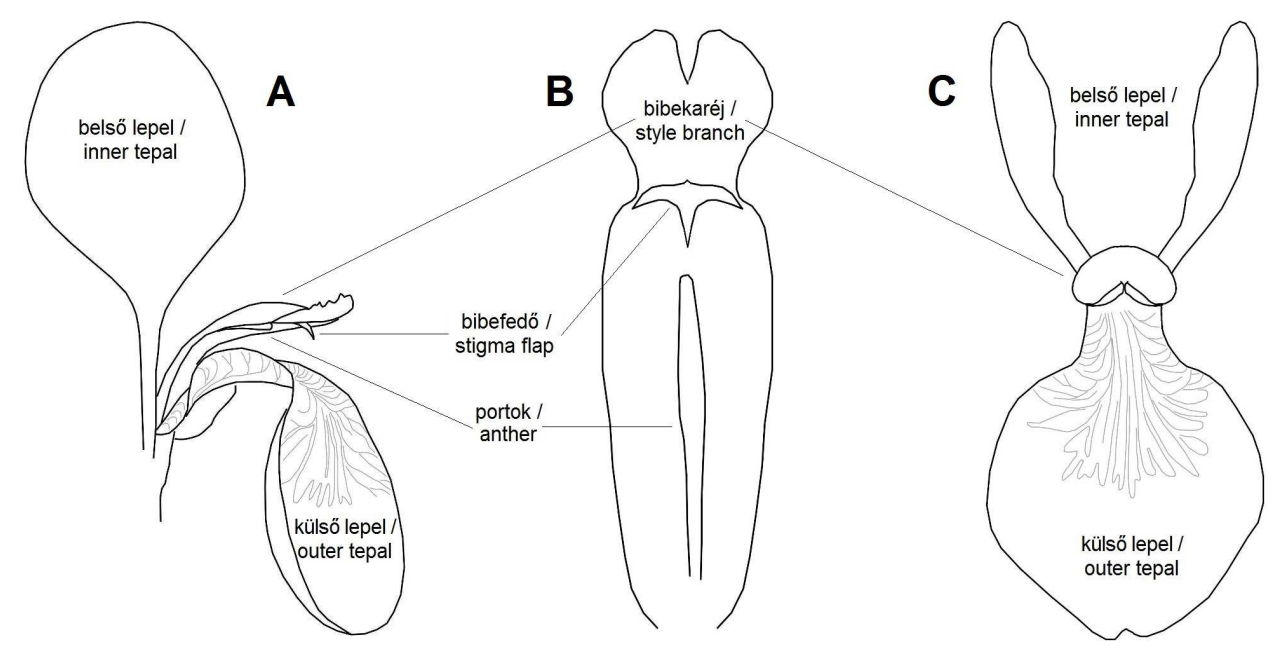

3. ábra. Az Iris-ek virágának zigomorf megporzási egysége (A) oldalról és (C) szemből; (B) a bibekaréj porzóval, alulnézetből (eredeti).

Fig. 3. The zigomorph pollination unit of an Iris flower from (A) side view and (C) front view; (B) the style branch and anther from bottom view (original).

\section{Szaporodás}

Generatív szaporodás

Az I. sibirica termésképzési sikerének illetve maghozamának összefüggése a virágzó hajtások számával, az egy időben nyíló virágok számával, a virágzat szintjeinek számával ellentmondásos, de valószínú, hogy az egyszerre nyíló virágok magas száma negatívan hat a reproduktív sikerre. A virágok nyílásának csúcsszezonjában a nagyobb számú virág egyidejû nyílása következtében nő a szomszédmegporzás (geitonogámia) valószínűsége, ami az ekkor 
képződő termések alacsonyabb magszámát eredményezi, míg a virágzás utolsó stádiumában a termésképzésre fordítható tápanyag korlátozott mennyisége miatt tovább csökken a termésenkénti magszám. A virágzási sorrendben egymást követő virágok egyre kisebb méretűek, a magházankénti magkezdemények száma is csökken, míg a pollen portokonkénti mennyisége és életképessége változatlan. Termésképzési aránya (10-)50-90\% között alakul (SzŐLLősI et al. 2010, 2011).

3. táblázat. Toktermések mérete és a magok termésenkénti száma egy regéci I. sibirica állományban, két egymást követő évben (eredeti adatok).

Table 3. Number of seeds and size of I. sibirica capsules in two consecutive years (original data from a population located near Regéc, NE-Hungary).

\begin{tabular}{|c|c|c|c|c|c|c|}
\hline & & 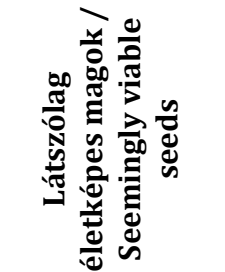 & 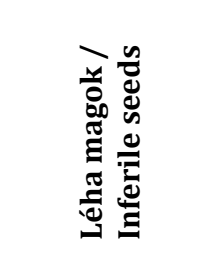 & 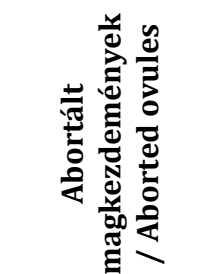 & 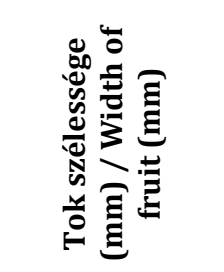 & 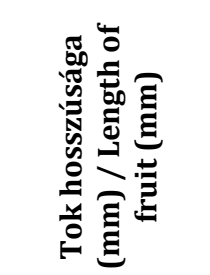 \\
\hline Év / Year & $\mathbf{n}$ & $\begin{array}{l}\text { átlag /mean } \\
\text { tartomány / range }\end{array}$ & $\begin{array}{l}\text { átlag /mean } \\
\text { tartomány / range }\end{array}$ & $\begin{array}{l}\text { átlag /mean } \\
\text { tartomány / range }\end{array}$ & $\begin{array}{c}\text { átlag /mean } \\
\text { tartomány / range }\end{array}$ & $\begin{array}{c}\text { átlag /mean } \\
\text { tartomány / range }\end{array}$ \\
\hline \multirow{2}{*}{2014} & \multirow{2}{*}{16} & 76,1 & 19,7 & 35,4 & 13,5 & 30,8 \\
\hline & & $33-121$ & $3-58$ & 10-95 & $10-17$ & $23-38$ \\
\hline \multirow{2}{*}{2015} & \multirow{2}{*}{33} & 58,1 & 17,4 & 40,9 & 12,5 & 29,1 \\
\hline & & $0-119$ & $0-68$ & $7-115$ & $9-18$ & $20-38$ \\
\hline
\end{tabular}

A magkezdeményeknek csak egy része termékenyül meg, és a megtermékenyülteknek is csak egy része fejlődik csíraképes maggá. Méretük és alakjuk alapján a pre- és posztzigotikusan abortálódott magkezdemények és magok megkülönböztethetők egymástól illetve az életképes magoktól (1. ábra). A magkezdemények (20-)60-80(-90)\%-a fejlődik életképes maggá (SzŐLLősı et al. 2010, 2011, 3. táblázat). NAGY (1927) szerint a magok korong alakúak, laposak, vékonyak. Megfigyeléseink szerint az életképes magok között alakjuk alapján további három típust különböztethetünk meg: i) többségük lapított, félkör kerületű, ezek a tok rekeszében egyenesen levágott oldalukkal egymás felé fordulnak, egymáshoz illeszkednek, szorosan kitöltve a rekeszt; ii) előfordulnak a rekesz teljes keresztmetszetét kitöltő, kör kerületű magok; iii) míg a rekesz elkeskenyedő alapi és csúcsi részén a magok kúposak. A magkezdemény anatróp, vagyis csúcsa (micropyle) a köldök felé fordul (NAGY 1927). Ezermagtömege 10-12 g között alakul, ami közeli rokonáétól, az $I$. pseudacorus-étól lényegesen elmarad (4. táblázat). NAGY (1927) szerint a nedves termőhelyeken előforduló $I$. sibirica magjai a nagyméretű, érett állapotban levegővel telt epidermisz- és parenchima sejteknek, valamint a felületi kutikula rétegnek köszönhetően hosszú időn keresztül a víz felszínén lebegnek, ami ártéri populációk esetében fontos a magvak terjedése szempontjából.

Lengyelországi tapasztalatok szerint kékperjés lápréteken csak a generatív tövek közelében mesterségesen kialakított, a növényzet, a holtavar és a mohatakaró eltávolításával létrehozott nyílt felszíneken képes magról újulni a növény (KosTRAKIEWICZ 2008, KOSTRAKIEWICZ-GIERAŁT 2012). Ugyanakkor, szintén Lengyelországban, egy regenerálódó kékperjés réten a tövek mintegy 81\%-a bizonyult juvenilisnek (SPOREK \& ROMBEL-BRYZEK 2005). Ecsetpázsitos mocsárréten egy rendszeresen monitorozott állományban DÉNES et al. (2008) új telepek megjelenését tapasztalták, amit magról való újulatként értékeltek. 
TAKÁCS et al. (2015) - Kitaibelia 20: 268-285.

4. táblázat. Az I. sibirica és néhány rokona ezermagtömeg adatai.

Table 4. Thousand-seed weight data of I. sibirica and some related taxa.

\begin{tabular}{lccl}
\hline \multicolumn{1}{c}{ Faj / Species } & $\begin{array}{c}\text { Ezermagtömeg (g) / } \\
\text { Thousand-seed weight (g) }\end{array}$ & $\begin{array}{c}\text { Gyújtőhely/ } \\
\text { Location }\end{array}$ & \multicolumn{1}{c}{ Forrás / Source } \\
\hline I. pseudacorus & 49,0000 & n.d. & Royal Botanic Gardens Kew \\
& 56,1400 & Debrecen & TöRöK et al. (2013) \\
\hline I. setosa & 6,16900 & n.d. & Royal Botanic Gardens Kew \\
\hline & 12,7977 & Aggtelek & TöRöK et al. (2013) \\
I. sibirica & 11,6100 & n.d. & Royal Botanic Gardens Kew \\
& 8,8298 & Regéc (2014) & ined. \\
& 10,8673 & Regéc (2015) & ined. \\
\hline I. virginica & 11,2914 & Tapolca (2014) & ined. \\
\hline
\end{tabular}

Vegetatív szaporodás

Kompetitív környezetben [amilyen például az erőteljes növekedésű, zsombékoló, évelő Molinia caerulea (L.) Moench. gyepje] az I. sibirica vegetatív szaporodása jelentősebb a generatívnál (KosTRAKIEWICZ 2008). Az idősödő polikormonok közepén elpusztulnak az elöregedő rizómarészletek, a polikormon gyűrű alakban nő tovább, majd feldarabolódik (KostraKIEWICZ 2007, DÉNES et al. 2008) (részletesebben lásd az Életciklus c. fejezetben). A vegetatív szaporodás dominanciájának demográfiai következménye, hogy a populációkban az egyedek többsége vagy akár az összes generatív, de elöregedő- illetve fragmentálódó stádiumban tart, míg a csíranövények, juvenilis- és fiatal generatív példányok hiányozhatnak (KosTRAKIEWICZ 2008). KOSTRAKIEWICZ \& WRÓBLEWSKA (2008) egy szubpopuláció-rendszer példáján vázolják fel a vegetatív szaporodás következményének betudható alacsony szintű genetikai változatosságot.

\section{Csíraképesség és növekedési ütem}

A csíráztatási kísérletünk során elvetett látszólag életképes magok (1. ábra D) csíranövényei a vetéstől számított 8 . és 26 . nap között jelentek meg. Legnagyobb arányban a szkarifikált magok csíráztak (14\%), míg a hütött és a fagyasztott magok esetében nem tapasztaltunk csírázást (5. táblázat). Úgy tűnik, az alacsony hőmérséklet dormanciát, míg a mechanikai szkarifikáció csírázást indukált. STANIŠıć et al. (2015) a maghéj eltávolítását követően agaróz gélre vetett magok esetében hosszabb periódusú és erősebb megvilágítás mellett ennél lényegesen magasabb csírázási arányt (76,38\%) tapasztaltak.

5. táblázat. Az I. sibirica magjainak csírázási arányai különböző kezeléseket követően (eredeti). Table 5. Germination rates of $I$. sibirica seeds after different treatments (original).

\begin{tabular}{lcc}
\hline \multicolumn{1}{c}{ Kezelés / Treatment } & $\begin{array}{c}\text { Csírázás aránya / } \\
\text { Germination rate }\end{array}$ & $\begin{array}{c}\text { Csírázás időszaka (vetéstől számított napok) / } \\
\text { Period of germination (days after sowing) }\end{array}$ \\
\hline áztatás / imbibing & $4 \%$ & $15-19$ \\
\hline hútés / cooling & $0 \%$ & - \\
\hline fagyasztás / refrigeration & $0 \%$ & - \\
\hline forrázás / scalding & $6 \%$ & $20-23$ \\
\hline szkarifikálás / scarification & $14 \%$ & $8-26$ \\
\hline kontroll / control & $4 \%$ & $16-20$ \\
\hline
\end{tabular}




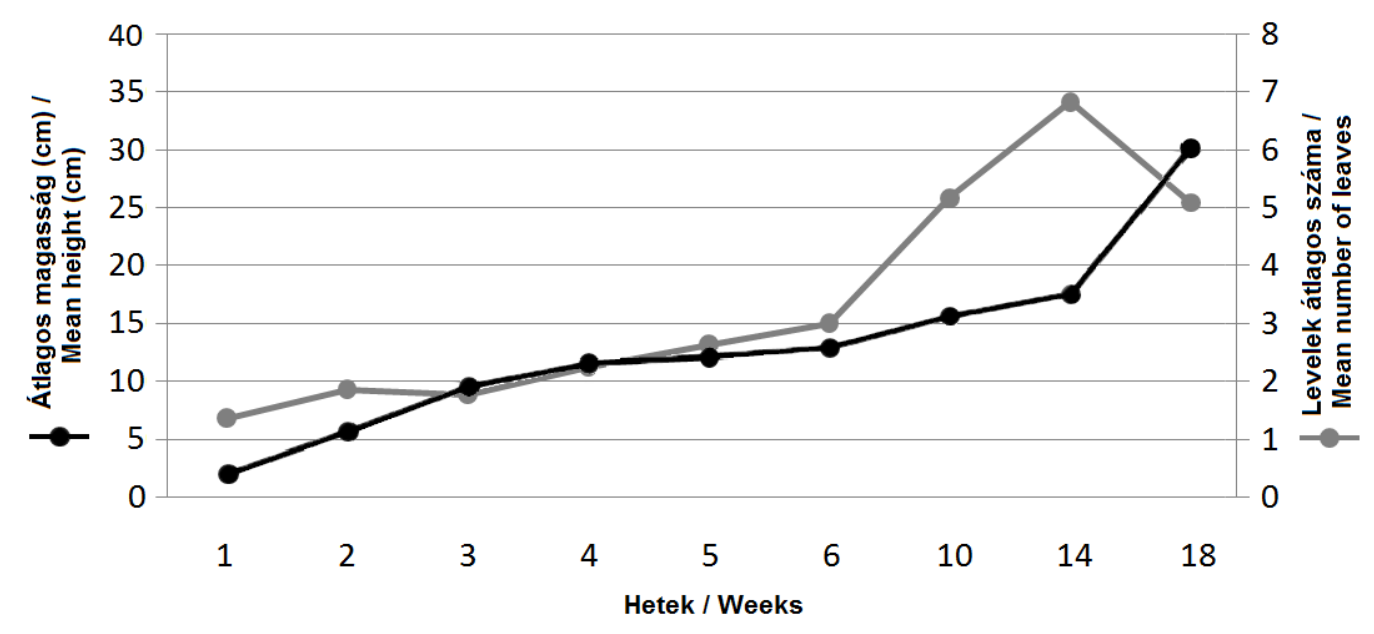

4. ábra. I. sibirica csíranövények átlagos növekedési üteme (eredeti).

Fig. 4. Growth rate of I. sibirica seedlings (original).

Az egyedek egyenletes ütemben növekedtek (4. ábra); a levelek átlagos számának csökkenése a 14. hét után a sziklevél és az azt követő néhány $\mathrm{cm}$ hosszúságú levelek elvesztésével magyarázható.

\section{Élőhelyigény és vegetációs preferencia}

Elterjedési területén alluviális és a lokálisan nedves, homokos vagy tőzeges talajú termőhelyeken egyaránt megtalálhatjuk. Ártéri a termőhelyeken gyakori lehet az elöntés, mely több hónapig is eltarthat a vegetációs időszakban. Elszigetelt populációit a víztestektől távolabbi, mérsékelten és időszakosan kedvező talajnedvességű termőhelyeken (például hegyi réteken) is megtalálhatjuk.

Növényközösségekben betöltött szerepe alapján specialista (S). A közép-kelet-európai flórára kidolgozott ökológiai indikátor-érték kategóriái besorolásában szubmontán hőklímában (TB6), időszakos elárasztást mutató (WB8), meszes (RB8) és erősen tápanyagszegény talajon (NB2), teljes megvilágításnak kitett mikroklímában (LB8), gyengén szubóceánikus és szubkontinentális helyzetben (KB8), a sós- és szikes termőhelyeket elkerülve (SB0) jellemző (BoRHIDI 1993).

Cönoszisztematikai besorolása szerint a nedves rétek (Molinio-Juncetea), a közép-európai rendszerben értelmezett üde kékperjés láprétek (Molinion) jellemző faja (BoRHIDI 1993, MOLNÁR \& RÉDEI 1995). Legjellemzőbb tömeges előfordulásai a lápi magaskórósokhoz (Filipendulo-Petasition Br.-Bl. ex Duvigneaud 1949) köthetők. Két asszociációban játszik jelentősebb szerepet: kisebb tömegességgel a sisakvirágosban [Aconitetum gracilis (Zólyomi 1934) Soó 1964], abundáns fajként a szibériai nőszirmosban (Iridetum sibiricae Philippi 1960), itt a társulás névadója (PHILIPPI 1960). Tömegessége a vegetatív szaporodás és az egymást követő sikeres virágzási-magképzési ciklusok együttes eredményeként alakul ki (DÉNES et al. 2008, SzőLLőSI et al. 2010). Színező elemként megtalálható számos üde és félnedves gyeptípusban: lápréteken, nedves kaszálókon, hegyi réteken, magassásosokban (például Carici vulpinae-Polygonetum bistortae Endes 2003 corr. Borhidi 2003, Caricetum davallianae Dutoit 1924, Seslerietum uliginosae Soó 1941, Juncetum subnodulosi Koch 1926, Cirsio cani-Festucetum pratensis Májovsky \& Ružičková 1975, Polygalo majorisBrachypodietum pinnati H. Wagner 1941) (KovÁcs 1962, BoRHIDI 2003). Fás életközösségekben a kiszáradó lápcserjések és láperdők [Molinio-Alnion glutinosae Kevey 2008] asszociáci- 
óiban szórványosan fordul elő (KEVEY 2008). A szibériai nőszirmot tartalmazó társulások a szüntaxonok természetvédelmi szempontú értékelése szerint védelemre (VJ) illetve fokozott védelemre (FVJ) javasoltak (BORHIDI \& SÁNTA 1999). Hazánkon kívül további közép-európai lokalitásokról jeleztek a szibériai nőszirom dominanciájával jellemezhető, hasonló fiziognómiájú állományokat, elsősorban a környező országok területéről (MORTON 1954, KORNECK 1962, IljuANić 1968, BALÁTOVÁ-TulačKovÁ \& HÜBl 1985, STRAKA \& EllmaUER 1990, KREWEdL 1992, BoHNER et al. 2001). A társulás az elmúlt évtizedekben több szüntaxonómiai rendszerbe formálisan is beépítésre került (OBERDORFER 1983, MuCiNA et al. 1993, РОTT 1995, BORHIDI 2003, CHYTRÝ 2007).

Aktuális hazai előfordulásairól és vegetációs preferenciájáról az utóbbi időkben BAUER et al. (2001), KESZEi (2002), SALAMON-ALBERT (2003), JuHÁSZ (2004), RiEZing (2005), SCHMIDT \& BAUER (2005), BoECKer et al. (2006), DÉNES et al. (2008), SALAMON-AlBERT et al. (2010), SALAMON-ALBERT \& LŐRinCZ (2010a,b), LÁJER et al. (2011), ÁdÁM \& MALATINSZKY (2012), BogYA et al. (2012), KALO \& TóTH (2012), RIEZING (2012) számolnak be.

17 hazai lelőhelyéről gyűjtött talajminták vizsgálata alapján erősen savanyútól a gyengén lúgosig, mészmentestől az erősen meszesig, többnyire magas humusz-, tág határok között változó foszfor-, kálium- és nitrogén tartalmú, alacsony sótartalmú vagy ritkán gyengén szoloncsákos, magas agyagtartalmú, kötött talajokon fordul elő (6. táblázat). Említett hazai lelőhelyein legkonzervatívabb termőhelyi talajtulajdonságnak a pH és a kötöttség, legváltozékonyabbnak pedig a szervetlen nitrogén- és foszfortartalom tűnik.

6. táblázat. Néhány talajparaméter az I. sibirica 17 magyarországi lelőhelyén (eredeti). Table 6. Characteristics of the soil at 17 localities with I. sibirica in Hungary (original).

\begin{tabular}{|c|c|c|c|c|c|c|c|c|}
\hline $\begin{array}{l}\text { Lelőhely / } \\
\text { Locality }\end{array}$ & pH (KCl) & $\mathbf{K}_{\mathbf{A}}$ & $\begin{array}{l}\text { Só / Salt } \\
(\mathrm{m} / \mathrm{m}) \%\end{array}$ & $\begin{array}{c}\mathrm{CaCO}_{3} \\
(\mathrm{~m} / \mathrm{m}) \%\end{array}$ & $\begin{array}{c}\text { Humusz } \\
\% \\
\end{array}$ & $\begin{array}{c}\mathbf{N O}_{2}+\mathbf{N O}_{3}-\mathbf{N} \\
\mathrm{mg} / \mathrm{kg}\end{array}$ & $\begin{array}{c}\mathbf{A L}-\mathbf{P}_{2} \mathbf{O}_{5} \\
\mathrm{mg} / \mathrm{kg}\end{array}$ & $\begin{array}{c}\mathbf{A L}-\mathbf{K}_{\mathbf{2}} \mathbf{O} \\
\mathrm{mg} / \mathrm{kg}\end{array}$ \\
\hline Csengőd & 7,15 & 88 & 0,10 & 49,72 & 12,29 & 76,09 & 386 & 95 \\
\hline Dabas & 7,70 & 79 & 0,03 & 29,7 & 5,65 & 11,9 & 216 & 334 \\
\hline Galgahévíz & 7,63 & 69 & 0,08 & 18,3 & 5,22 & 9,38 & 82 & 78 \\
\hline Kerkabarabás & 4,15 & 63 & $<0,02$ & $<0,05$ & 4,40 & 393,7 & 57 & 206 \\
\hline Köveskál & 7,14 & 77 & 0,04 & 34,43 & 5,19 & 24,9 & 25 & 134 \\
\hline Létavértes & 7,18 & 83 & 0,03 & 38,06 & 9,69 & 24,8 & 175 & 136 \\
\hline Mórahalom & 7,61 & 65 & 0,08 & 31,5 & 5,3 & 30,7 & 94 & 196 \\
\hline Nemesnép & 6,95 & 59 & $<0,02$ & 6,47 & 3,28 & 2,5 & 133 & 233 \\
\hline Nyírábrány & 7,22 & 57 & $<0,02$ & 27,07 & 4,61 & 4,2 & 119 & 146 \\
\hline Nyirád & 6,30 & 68 & $<0,02$ & $<0,05$ & 5,21 & 1,21 & 63 & 89 \\
\hline Pellérd & 7,26 & 65 & 0,07 & 6,74 & 5,24 & 19,1 & 148 & 342 \\
\hline Pusztavám & 7,50 & 58 & $<0,02$ & 16,7 & 3,05 & 5,72 & 47 & 47 \\
\hline Regéc & 4,13 & 69 & $<0,02$ & $<0,05$ & 7,50 & $<2,0$ & 77 & 194 \\
\hline Rezi & 7,53 & 95 & 0,08 & 42,26 & 15,05 & 82,75 & 172 & 105 \\
\hline Sopron & 7,36 & 70 & $<0,02$ & 28,5 & 5,14 & 22,9 & 76 & 85 \\
\hline Szécsény & 7,04 & 80 & 0,10 & 1,10 & 3,83 & $<2,0$ & 402 & 382 \\
\hline Tapolca & 7,26 & 56 & 0,04 & 2,45 & 7,07 & 55,0 & 103 & 148 \\
\hline Medián / median & 7,22 & 69 & 0,08 & 27,8 & 5,22 & 22,9 & 103 & 146 \\
\hline Szórás / SD & 1,08 & 11 & 0,03 & 15,4 & 3,22 & 98,2 & 108 & 100 \\
\hline
\end{tabular}

Eredményeinket összevetve stájerországi mérésekkel (BoHNER et al. 2001) azt tapasztaljuk, hogy ott jellemzően alacsonyabb pH-tartományban fordul elő a faj, amit a humidabb klímával összefüggő mészkerülő termőhelyek túlsúlya magyarázhat. A kémhatás tartományának változatossága a faj pH toleranciájára enged következtetni (amely ellentmond az RB8 besorolásnak). Ugyanitt (Stájerország, Ausztria) termőhelyei BoHNER et al. (2001) szerint 
szarvasmarha legeltetésére alkalmatlanok. A BoHNER et al. (2001) által tanulmányozott $I$. sibirica termőhelyeken a talaj feletti biomassza viszonylag szegény nitrogénben, foszforban, káliumban és nátriumban, viszont a kálcium-, magnézium-, vas-, mangán-, cink-, kobalt-, króm-, kadmium-, ólom- és arzéntartalma jelentős lehet. A viszonylag magas nehézfém- és arzéntartalmat a hidromorf talajjal és a kétszikűekben gazdag vegetációval hozzák összefüggésbe.

\section{Elterjedés}

A faj euroszibériai flóraelem, elterjedése Közép-Európától Nyugat-Szibériáig, csaknem a Jenyiszej-folyóig húzódik (5. ábra, HulTÉn \& FRIES 1986, MEUSEL \& JÄGER 1992). Vertikális elterjedése a síkságoktól a prealpin tájakig terjed (Soó 1973).

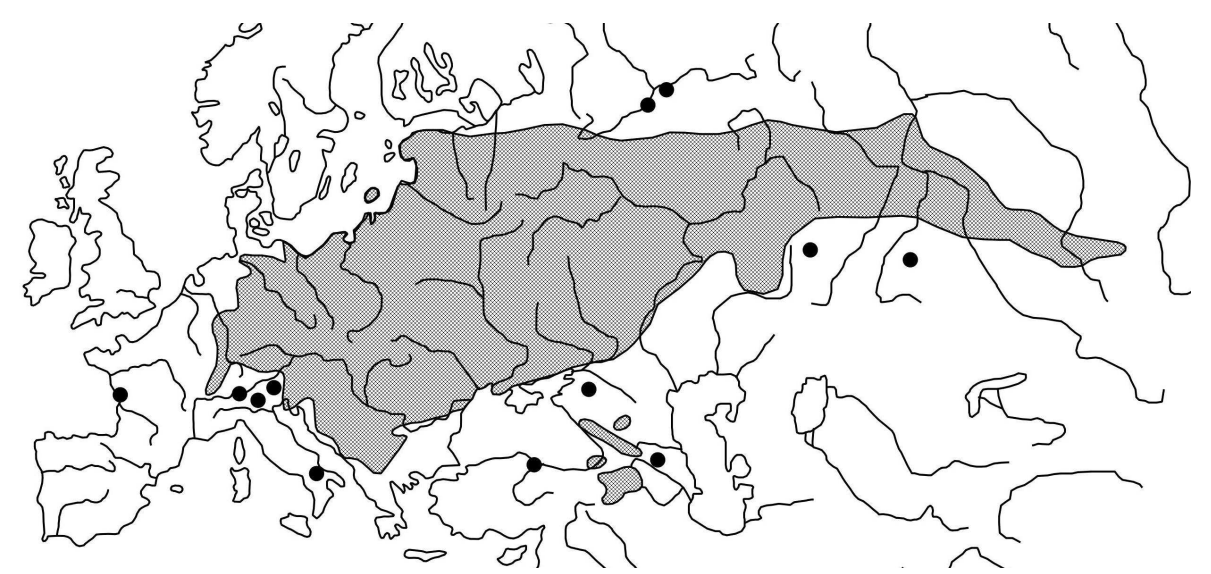

5. ábra. Az I. sibirica elterjedése és szórvány-előfordulásai MeUSEL \& JÄGER (1992) nyomán.

Fig. 5. Distribution range and remote occurrences of I. sibirica, based on MEUSEL \& JäGER (1992).

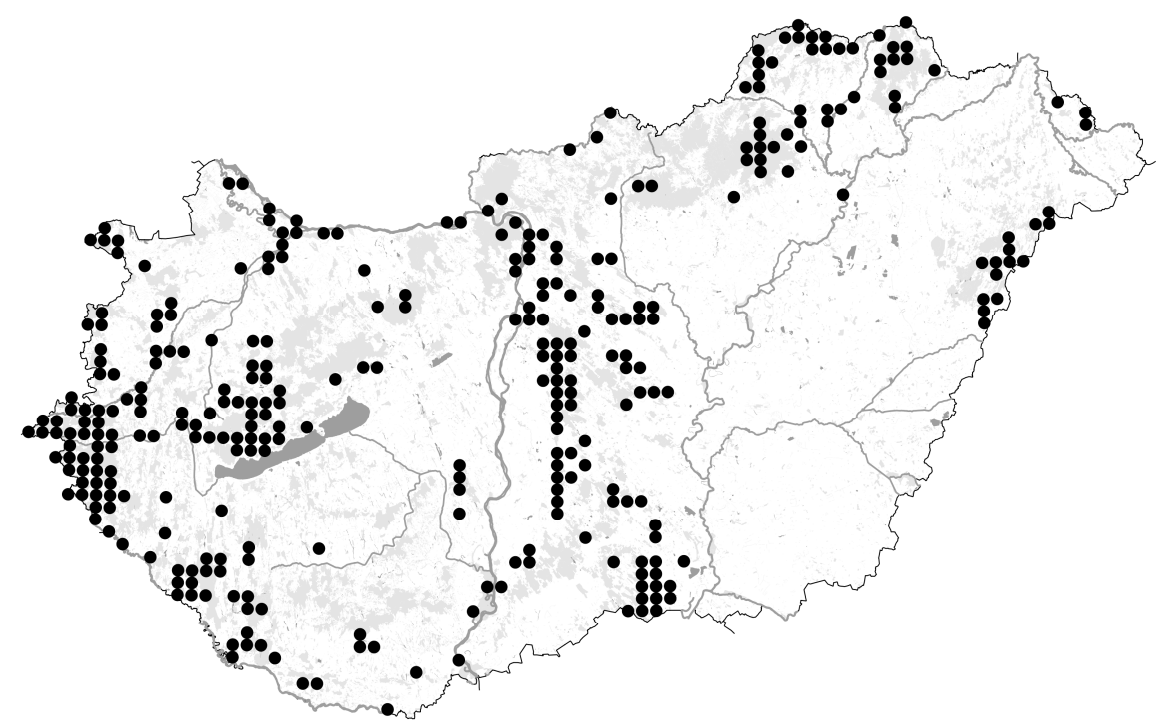

6. ábra. Az I. sibirica hazai elterjedése a Magyar Flóratérképezési Program Adatbázisa és a BotanikaSE adatbázis alapján.

Fig. 6. Distribution of I. sibirica in Hungary based on the Database of Hungarian Flora Mapping System and the BotanikaSE database. 
Változó gyakorisággal, de Magyarország egész területén előfordul. Legritkább a Tiszántúlon, amelynek csak peremterületein ismert, leggyakoribbnak pedig a Nyugat-Dunántúlon mondható (6. ábra). Hazai elterjedése igen hasonló a kékperjés rétekéhez (vö. LÁJER et al. 2011).

\section{Biotikus interakciók}

Az I. sibirica hajtásai keserű ízűek (GonTova \& ZATYLNIKOVA 2013), feltehetően ennek köszönhető, hogy legelő állatok jellemzően nem károsítják (CSAPODY 1982), termésein viszont elhanyagolható mértékű, egyelőre ismeretlen rovarok okozta kártétel előfordul (saját megfigyelés). Növényünk több mikrogomba gazdanövényeként is ismert, így kimutatták már róla az Alternaria alternata (Fr.) Keissl., Botrytis cinerea Pers., Eudarluca caricis (Biv.) O. E. Erikss., Fusarium poae (Peck) Wollenw., F. sporotrichioides Sherb., Mucor sp., Periconia sp., Puccinia iridis Wallr., Septoria iridis C. Massal., Trichoderma sp. gombák jelenlétét (XU et al. 2013, JANDRASITS \& FISCHL 2014). Az I. sibirica gyökereiben vezikuláris-arbuszkularis mikorrhiza (VAM) észlelhető, amely foszforban szegény talajokon segítheti a növény foszforfelvételét (BOHNER et al. 2001).

\section{Biológiailag aktív anyagok}

Az I. sibirica rizómáiból izoláltak elsőként néhány ritka monociklikus triterpenoidot (MARNER \& LONGERICH 1992, MARNER et al. 1995). KRECHUN \& ZATYLNIKOVA (2013) szárított, porrá őrölt gyökereinek biológiailag aktív anyagai (triterpenoid szaponinok, tanninok, flavonoidok, kumarinok) alapján alkalmas gyógynövénynek találták, mint köptető, gyulladáscsökkento, savlekötő hatású drogot.

\section{Mikroszaporítás}

STANIŠIĆ et al. (2015) az I. sibirica in vitro mikroszaporítására kidolgozott protokollt mutatják be: munkájuk során levél-implantátumokból kiindulva organogenezist és szomatikus embriogenezist indukáltak. Hogy a mikroszaporítással létrehozott utódok genetikailag nem változtak (nem sérültek), áramlási citometria, kromoszómaszámlálás és RAPD módszer eredményeivel igazolták.

\section{Felhasználás}

A nőszirmok rizómái általában epehajtó, májvédő, hashajtó, vértisztító, vizelethajtó, gyulladáscsökkentő hatású drogként ismertek (például HoFFMANN 2003). Konkrétan az $I$. sibirica kapcsán kevés az erre vonatkozó ismert adat, de egyes szerzők (GoNTOVA \& ZATYLNIKOVA 2013, KRECHUN \& ZATYLNIKOVA 2013) említik a növény népi gyógyászatban való alkalmazását.

GAO et al. (2014) tápanyagokkal (nitrogénnel és foszforral) túlterhelt víz tisztítására alkalmazták egy kísérlet erejéig. A tápanyag kihozatal a terhelés mértékével együtt nőtt, de az erősen és közepesen terhelt vízből nagyobb arányban nyerte ki a tápanyagokat, mint a kevéssé szennyezettből. Az eredmény annak fényében még érdekesebb, hogy mindez a nitrifikáció számára optimálisnál alacsonyabb hőmérsékleten történt (a téli időszak körülményeit modellezték). A nitrogén és foszfor akkumuláció jelentősebb volt a föld alatti, mint a föld feletti hajtásban. Összességében alkalmasnak találták az I. sibirica-t eutróf vizek tisztítására. 
Dísznövényként gyakran ültetik, főként kerti tavak partjára. Becslések szerint több száz termesztett változata és mesterséges hibridje létezik (SPEICHERT \& SPEICHERT 2004), amelyek széles körben kaphatóak a kertészetekben.

KAŠŠÁK \& KULI (2014) az I. sibirica kertészeti fajtáit, mint festőnövényeket vizsgálták, bíztató eredményekkel.

\section{Veszélyeztetettség és védelem}

NÉMETH (1990) és KIRÁLY (2007) a potenciálisan veszélyeztetett, (NT) fajok közé sorolják. Csehországban (Grulich 2012) és Szlovákiában (TuRIS et al. 2014) sérülékeny (Vulnerable), Romániában (OPREA 2005) szórványos (Sporadic) fajként tartják számon.

Hazánkban 1982 óta törvényes oltalmat élvez. Pénzben kifejezett értéke $10000 \mathrm{Ft}$. Ahol lakott terület közelében nagyobb állományai élnek, védelme ellenére gyakran kiássák és kertekbe, temetókbe ültetik.

CSAPODY (1982) az I. sibirica védelme érdekében legfontosabb feladatnak élőhelyei védelmét (talajvízszint megtartása, rétek fenntartása stb.) tekinti. SPOREK \& ROMBEL-BRYZEK (2005) is ezt hangsúlyozzák, valamint bemutatják egy kiszárított, majd a vízkormányzás felhagyását követően regenerálódott kékperjés rét I. sibirica populációjának gyarapodását. Növényünknek hazánkban ma még jelentős állományai élnek, ám élőhelyeinek leromlása hosszútávon fenyegető lehet (vö. Kostrakiewicz 2008, KostraKIEWICZ-GiERAŁT 2012). KOSTRAKIEWICZ \& WRÓBLEWSKA (2008) szerint a szubpopulációkon belüli csekély genetikai sokféleség illetve a szubpopulációk közti jelentős különbség a vegetatív szaporodás dominanciájának és a szubpopulációk elszigetelődésének, vagyis az élőhely leromlásának és fragmentációjának tudható be.

CSAPODY (1982) és DÉNES et al. (2008) az I. sibirica védelme érdekében a késői, termésérést követő kaszálást javasolják, míg TöRöK et al. (2007) tapasztalatai szerint a rendszeres kaszálás hatására némileg megritkul a növény.

\section{Köszönetnyilvánítás}

A kutatás a TÁMOP-4.2.4.A/2-11/1-2012-0001 és TÁMOP-4.2.2.B-15/1/KONV-2015-0001 programok keretében, az OTKA K108992 pályázat támogatásával valósult meg. Köszönettel tartozunk Barina Zoltánnak (BP) valamint Isépy Istvánnak és ifj. Papp Lászlónak (BPU) a herbáriumi adatgyújtés feltételeinek megteremtéséért, Schmidt Dávidnak és Bartha Dénesnek a Magyar Flóratérképezési Program Adatbázisa (Nyugat-magyarországi Egyetem, EMK, Növénytani és Természetvédelmi Intézet Sopron) elterjedési adatainak közléséért, Farkas Sándornak a BotanikaSE adatbázis adatainak közléséért, Lukács Balázs Andrásnak és E. Vojtkó Annának a levél-tulajdonság adatok méréséért. Hálásak vagyunk Barina Zoltánnak, Mihalik Erzsébetnek és Papp Máriának a kézirathoz füzött igen hasznos lektori észrevételeikért.

\section{Irodalom}

ÁDÁm Sz. \& MALATıNSZKY Á. (2012): Florisztikai adatok a Duna egyes szigeteiről. - Kitaibelia 17: 69.

BALÁtovÁ-TulaČKovÁ E. \& HÜBl E. (1985): Feuchtbiotope aus den nordöstlichen Alpen uns aus der Böhmischen Masse. - Angewandte Pflanzensoziologie Wien 29: 1-131.

BAUER N., BALOGH L. \& KENYERES Z. (2001): A tapolcafói és az attyai láprét vegetációja és természetvédelmi problémái (Pápai Bakonyalja). - Botanikai Közlemények 88: 71-94.

BERNÁTSKY J. (1911): A hazai Iris-félék. - Mathematikai és természettudományi közlemények 31: 437-575.

BOECKER D., TuRCSÁNYI G. \& MÖSELER B. (2006): Floristisch-vegetationskundliche Untersuchung der Moorwiese bei Galgahévíz zur Erstellung eines Biotoppflegeplanes. - Tájökológiai Lapok 4: 347-356. 
BogYA S., LuKÁCS A., BotTLIK G. \& BARABÁS S. (2012): Az M0 autóút nyomvonalából végzett növénymentés tapasztalatai és eredményei a Soroksári Botanikus Kert láprétjén. - Kitaibelia 17: 73.

Bohner A., Sobotik M. \& ZeChner L. (2001): Die Iris-Wiesen (Iridetum sibiricae Philippi 1960) im Mittleren Steirischen Ennstal (Steiermark, Österreich) - Ökologie, Soziologie und Naturschutz. Tuexenia 21: 133-151.

Borhidi A. (1993): A Magyar flóra szociális magatartás típusai, természetességi és relatív ökológiai értékszámai. - KTMHT és JPTE kiadványa, Pécs, 93 pp.

BoRHIDI A. (2003): Magyarország növénytársulásai. - Akadémiai Kiadó, Budapest, pp. 151-156.

Borhidi A. \& SÁNTA A. (szerk.) (1999): Vörös Könyv Magyarország növénytársulásairól 1. TermészetBúvár Alapítvány Kiadó, Budapest, pp. 266-288.

ChYTRÝ M. (ed.) (2007): Vegetáce České republiky 1. Travinná a keříčková vegetáce. - Academia, Praha, 526 pp.

Cigić P., ReŠEtNiK I., Liber Z., Nikolić T., Dobrović I. \& Mitić B. (2006): Taxonomic research of the species Iris sibirica sensu lato (Iridaceae). - IV. Balkan Botanical Congress "Plant, fungal and habitats diversity investigation and conservation", Bulgaria, Sofia, 20-26.06.2006.

CSAPODY I. (1982): Védett növényeink. - Gondolat Könyvkiadó, Budapest.

DÉNes A., JuhÁsz M. \& SALAmon-AlBert É. (2008): A szibériai nőszirom (Iris sibirica L.) egy Dráva menti állományának változásai 2000-2007 között. - Somogyi Múzeumok Közleményei 18: 7-15.

DiósZEGI S. \& FAZEKAS M. (1807): Magyar füvész-könyv, melly a két magyar hazában található növényeknek megismertethetésére vezet, a Linné alkotmánya szerint. - Debrecen, 608 pp.

FARKAS S. \& MolNÁR V. A. (2014): Az „Év vadvirága” mozgalom Magyarországon. - Kitaibelia 19: 349-353.

GAO J., WANG W., Guo X., Zhu S., Chen S. \& ZhANG R. (2014): Nutrient removal capability and growth characteristics of Iris sibirica in subsurface vertical flow constructed wetlands in winter. Ecological Egineering 70: 351-361.

Goldblatt P. \& Johnson D. E. (eds) (1979-2015): Index to plant chromosome numbers. - Missouri Botanical Garden, St. Louis.

Goldblatt P., Manning J. C. \& Rudall P. (1998): Iridaceae. - In: KuBitzKi K. (ed.), The families and genera of vascular plants. Vol. III. Flowering plants, monocotyledons. Springer-Verlag, Berlin-Heidelberg, Germany, pp. 295-325.

Gontova T. N. \& ZatYlnikova O. A. (2013): Comparative morphological and anatmical study of leaves and stems of Iris pseudacorus and Iris sibirica. - International Journal of Pharmacy and Pharmaceutical Science 5: 574-578.

GRULICH V. (2012): Red List of vascular plants of the Czech Republic: 3rd edition. - Preslia 84: 631-645.

HofFmann D. (2003): Medicinal herbalism. The science and practice of herbal medicine. - Healing Arts Press, Rochester.

HULtÉN E. \& FRIES M. (1986): Atlas of North European vascular plants: north of the Tropic of Cancer, I-III. - Koeltz Scientific Books, Königstein.

ILIJANIĆ L. J. (1968): Die Ordnung Molinietalia in der Vegetation Nordostkroatiens. - Acta Botanica Croatica 26-27: 161-180.

JANDRASITS L. \& FISCHL G. (2014): Védett növényfajok mikroszkopikus gombái az Őrségi Nemzeti Parkban és környékén. - Kitaibelia 19: 187-211.

Jávorka S. (szerk.)(1925): Magyar Flóra (Flora Hungarica). - Magyar Nemzeti Múzeum Növénytára és Studium Könyvkiadó Rt., Budapest.

JuHász M. (2004): A somogyi Dráva-ártér növényzete. - In: SAlLAI Z. (szerk.), A drávai táj természeti értékei. Nimfea Tanulmánykötetek 3: 20-28.

KALO M. \& TóTH Z. (2012): A Balaton-felvidéki Fekete-hegy flórája és élőhelytípusai. - Kitaibelia 17: 107.

KAŠš́́K P. \& KULI M. (2014): Dyeing potential of the Iris sibirica L. flowers. - European Scientific Journal 2: 372-380.

KeszEI B. (2002): A Répce-menti rétek vegetációja Keményegerszeg térségében. - Vasi Szemle 56: 64-74.

KEvEY B. (2008): Magyarország erdőtársulásai. - Tilia 14: 1-489.

KIRÁLY G. (szerk.) (2009): Új magyar füvészkönyv. Magyarország hajtásos növényei. Határozókulcsok. Aggteleki Nemzeti Park Igazgatóság, Jósvafő.

KIRÁLY G. (szerk.) (2007): Vörös Lista. A magyarországi edényes flóra veszélyeztetett fajai. - Saját kiadás, Sopron.

KonNECK D. (1962): Die Pfeifengraswiesen und ihre Wichtingsten Kontaktgesellschaften in der nördlichen Oberrheinebene und im Schweinfurter Trockengebiet. Teil II. - Beitrage Naturkundliche Forschung Südwestdeutschlands (Karlsruhe) 21: 165-190. 
KostraKiEWicz K. (2007): The effect of dominant species on numbers and age structure of Iris sibirica L. population on blue moor-grass meadow in Southern Poland. - Acta Societatis Botanicorum Poloniae 76: 165-173.

Kostrakiewicz K. (2008): Population structure of a clonal endangered plant species Iris sibirica L. in different habitat conditions. - Polish Journal of Ecology 56: 581-592.

KostRAKIEWICZ-GIERAET K. (2012): The impact of neighbourhood and gap character on seedling recruitment of Trollius europaeus L. and Iris sibirica L. in Molinietum caerulae meadows. Biodiversity Research and Conservation 28: 37-44.

KostraKieWicz K. \& WRóBleWSKA A. (2008): Low genetic variation in subpopulations of an endangered clonal plant Iris sibirica in southern Poland. - Annales Botanici Fennici 45: 186-194.

KovÁcs M. (1962): Die Moorwiesen Ungarns. Magyarország láprétjei. - In: ZóLYomi B. (szerk.), A Magyar Tájak Növénytakarója 3. Akadémiai Kiadó, Budapest, 214 pp.

Krechun A. V. \& ZATYLNiKova O. A. (2013): Research of the chemical composition of biologically active substances of Iris sibirica L. - Actual questions of development of new drugs: book of abstracts of XX. international scientific and practical conference of young scientists and students. April 25-26, 2013, Kharkiv.

KREwedL G. (1992): Die Vegetation von Naßstandorten im Inntal Zwischen Telfs und Vörgl. Grundlagen für den Schutz bedrohter Lebensräume. - Berichte Naturwissenschaftlich Medizinischer Verein Innsbruck Supplement 9: 1-464.

LÁjer K., MÁté A., SERegélyes T., BAGi I. \& Molnár Zs. (2011): D2 - Kékperjés rétek. Molinia meadows. In: BöLÖNI J., MolnÁR Zs. \& Kun A. (szerk.), Magyarország élőhelyei. A hazai vegetációtípusok leírása és határozója. ÁNÉR 2011. MTA ÖBKI, pp. 80-85.

LAWRENCE G. H. M. (1953): A reclassification of the genus Iris. - Gentes Herbarium 8: 346-371.

LinNaEus C. (1753): Species Plantarum, exhibentes plantas rite cognitas, ad genera relatas, cum differentiis specificis, nominibus trivialibus, synonymis selectis, locis natalibus, secundum systema sexuale digestas. Tomis I. - Laurentius Salvius, Stockholm, p. 39.

Malakhova L. A. \& Markova G. A. (1994): Chromosome numbers in the flowering plants of Tomsk region. Monocotyledones. - Botaničeskij Žurnal (Moscow \& Leningrad) 79: 134-135.

MARNER F.-J. \& LONGERICH I. (1992): Isolation and Structure Determination of New Iridals from Iris sibirica and Iris versicolor. - Liebigs Annalen der Chemie 1992 (3): 269-272.

MARNER F.-J., Simic K., ScHolz B. \& KüSTER B. (1995): Isolation and structure determination of a new iridal from Iris sibirica. - Journal of Natural Products 58: 299-301.

Meusel H. \& JÄGER E. (1992): Vergleichende Chorologie der Zentraleuropäischen Flora, Vol. 1. - Gustav Fischer Verlag, Germany, Jena.

Molnár V. A. (2007): A „Magyar Fűvész Könyv” megjelenésének 200. évfordulójára. - Botanikai Közlemények 94: 141-153.

MoLNÁR Zs. \& RÉDEI T. (1995): A hazai edényes flóra cönoszisztematikai besorolásának Soó-i rendszere. In: Horváth F., Dobolyi K. Z., MorschHauser T., LőKös L., Karas L. \& Szerdahelyi T. (szerk.), Flóra Adatbázis 1.2. Taxon-lista és attribútum-állomány. Flóra Munkacsoport, MTA Ökológiai és Botanikai Kutatóintézete és MTM Növénytár, Vácrátót - Budapest, pp. 24-38.

MoRTon F. (1954): Über das Vorkommen der Iris sibirica im Salzkammergute. - Angewandte Pflanzensoziologie Wien, Festschrift Aichinger: 667-673.

Mucina L., GrabherR G. \& Ellmauer, T. (1993): Die Pflanzengesellschaften Österreichs Teil I. Anthropogene Vegetation. - Gustav Fischer Verlag, Jena, Stuttgart, New York, 329 pp.

MuRin A. (1976): In Index of chromosome numbers of Slovakian flora. Part 5. - Acta Facultatis Rerum Naturalium Universitatis Comenianae Botanica 25: 1-18.

NAGY J. (1927): Adatok az Iris-magvak anatómiájának ismertetéséhez. - Botanikai Közlemények 24: 30-47.

NÉMETH F. (1990): Száras növények (Vascular plants). - In: RAKoncZAY Z. (szerk.), Vörös Könyv. A Magyarorszáról kipusztult és veszélyeztetett növény- és állatfajok. - Akadémiai Kiadó, Budapest, pp. 265-325.

OBERDORFER E. (1983): Süddeutsche Pflanzengesellschaften Teil III. - 2. Aufl. Stuttgart, New York, 455 pp.

ODInTSOva A. \& SKRIPETS X. (2014): Nowi dani stsodo zapilennja Iris sibirica L. (Iridaceae). - Studia Biologica 8: 197-208.

OPREA A. (2005): Lista critică a plantelor vasculare din România. - Editora Universităţii „Alexandru Ioan Cuza" Iaşi.

PAPP D. (1903): Adatok az Iris-ek levelének tanulmányozásához. - Növénytani Közlemények 2: 41-72. 
PHILIPPI G. (1960): Zur Gliederung der Pfeifengraswiesen im südlichen und mittleren Oberr-heingebiet. - Beitrage Naturkundliche Forschung Südwestdeutschlands (Karlsruhe) 19: 138-187.

Pотт R. (1995): Die Pflanzengesellschaften Deutschlands. - Verlag Eugen Ulmer, Stuttgart, pp. 324-325.

RAPAics R. (1932): A magyarság virágai. A virágkultusz története. - Királyi Magyar Természettudományi Társulat, Budapest, pp. 97-99.

RiEziNG N. (2005): Adatok a Gönyű-Neszmély közötti Duna-szakasz flórájához és vegetációjához. Botanikai Közlemények 92: 57-67.

RIEZING N. (2012): Adatok a Győr-Tatai Kisalföld flórájához és vegetációjához. - Botanikai Közlemények 99: 81-102.

Rodionenko G. I. (1987): The genus Iris L. (Questions of morphology, biology, evolution and systematics). British Iris Society, London.

Royal Botanic Gardens Kew (2015): Seed Information Database (SID). Version 7.1. http://data.kew.org/sid/ (Hozzáférés: 2015.08.01.)

SALAmon-Albert É. (2003): On the relation between habitat indication and vegetation pattern in wet meadows: ecoindicational evaluation. - Acta Botanica Hungarica 45: 373-388.

SAlAmon-Albert É. \& Lőrincz P. (2010a): Coenological status of Iridetum sibiricae Philippi 1960 in Hungary. - Annali di Botanica Nuova Serie 9: 23-28.

SALAMON-AlBERT É. \& LőRINCZ P. (2010b): Szibériai nőszirmos gyepek szerveződése és természetvédelmi helyzete a Mecsek déli lábánál. - Dunántúli Dolgozatok (A) Természettudományi Sorozat 12: 168-181.

SAlAmon-Albert É., LőRincz P. \& Borhidi A. (2010): Iridetum sibiricae Philippi 1960 in Hungary. - Acta Botanica Hungarica 52: 177-196.

SCHмidT D. \& BAUER N. (2005): Adatok a Kisalföld flórájának ismeretéhez. - Botanikai Közlemények 92: 43-56.

Simon T. (2002): A magyarországi edényes flóra határozója. Harasztok - virágos növények. - Nemzeti Tankönyvkiadó, Budapest.

Soó R. (1973): A magyar flóra és vegetáció rendszertani-növényföldrajzi kézikönyve. Synopsis systematico-geobotanica Florae Vegetationisque Hungariae V. - Akadémiai Kiadó, Budapest.

SPEICHERT G. \& SPEICHERT S. (2004): Encyclopedia of Water Garden Plants. - Timber Press, Portland.

Sporek M. \& Rombel-BryzeK A. (2005): Wetland restoration enhances the development of protected species (Iris sibirica L.) - A case study. - Polish Journal of Ecology 53: 591-595.

Stanišić M., Raspor M., Ninković S., MilošEvić S., Ćalić D., Bohanec B., Trifunović M., Petrić M., Subotić A. \& JEVREMOVIĆ S. (2015): Clonal fidelity of Iris sibirica plants regenerated by somatic embryogenesis and organogenesis in leaf-base culture - RAPD and flow cytometer analyses. - South African Journal of Botany 96: 42-52.

Stebings G. (1997): The Gardener's Guide to Growing Irises. - Newton Abbot: David and Charles.

Straka A. \& Ellmauer T. (1990): Die Wiesen des Stockerauer Augebietes. - Manuskript, ARGE f. Naturschutzforschung und Angewandte Vegetationsökologie, Wien.

SZŐLLősI R., MEDVEGY A., NÉMETH A., KÁLMÁN K. \& MihALIK E. (2010): Intra-inflorescence variations in floral morphological and reproductive traits of Iris sibirica. - Acta Biologica Szegediensis 54: 103-110.

SzőLlősi R., MEdvegy A., BenYes E., NÉmeth A. \& Minalik E. (2011): Flowering phenology, floral display and reproductive success of Iris sibirica. - Acta Botanica Hungarica 53: 409-422.

TAYLOR J. J. (1976): A reclassification of Iris species bearing arillate seeds. - Proceedings of the Biological Society, Washington 89: 411-420.

Török P., ARAny I., Prommer M., VAlKó O., Balogh A., VidA E., Tóthmérész B. \& Matus G. (2007): Újrakezdett kezelés hatása fokozottan védett kékperjés láprét fitomasszájára, faj- és virággazdagságára. Természetvédelmi Közlemények 13: 187-198.

TöröK P., Miglécz T., ValKó O., Tóth K., Kelemen A., Albert Á., Matus G., Molnár V. A., Ruprecht E., Papp L., DeÁK B., Horváth O., TAKÁCS A., HÜSE B. \& TóthméRÉSz B. (2013): New thousand-seed weight records of the Pannonian flora and their application in analysing Social Behaviour Types. - Acta Botanica Hungarica 55: 429-472.

Turis P., Kliment J., FeráKová V., DítĚ D., Eliáš P., Hrivnák R., KoŠŤÁL J., Šuvada R. \& Mráz P. \& Bernátová, D. (2014): Red List of vascular plants of the Carpathian part of Slovakia. - Thaiszia 24: 35-87.

Tutin T. G. (1980): Iris L. (incl. Xiphion Miller). - In: TutıN T. G. (ed.), Florae Europaea. Vol. 5. Cambridge University Press, Cambridge.

Wetschnig W. (1988): Chromosomenzahlen Kärntner Gefässpflanzen (Teil 1). - Carinthia II 178: 391401. 
TAKÁCS et al. (2015) - Kitaibelia 20: 268-285.

WiLSON C. A. (2004): Phylogeny of Iris based on chloroplast matK gene and trnK intron sequence data. Molecular Phylogenetics and Evolution 33: 402-412.

WiLSON C. A. (2009): Phylogenetic relationships among the recognized series in Iris Section Limniris. Systematic Botany 34: 277-284.

Xu B., Zhao Z.-Y. \& ZhuAng J.-Y. (2013): Rust fungi hitherto known from Xinjiang (Sinkiang), northwestern China. - Mycosystema 32: 170-189.

Beérkezett / received: 2015. 09. 12. • Elfogadva / accepted: 2015. 10. 09. 